\title{
PETERNAK KAMBING DESA SINDON KECAMATAN NGEMPLAK BOYOLALI
}

\section{(GOAT LIVESTOCK AT DESA SINDON KECAMATAN NGEMPLAK BOYOLALI)}

\author{
Haryoto $^{1}$, Muhtadi ${ }^{2}$, Rusdin Rauf ${ }^{3}$ \\ ${ }^{1,2}$ Fakultas Farmasi, Universitas Muhammadiyah Surakarta, ${ }^{3}$ Fakultas Ilmu Kesehatan, \\ Universitas Muhammadiyah Surakarta \\ e-mail: haryoto@ums.ac.id
}

\begin{abstract}
The issue of animal feed and the efficiency of the goat breeding production process, is still a big problem for conventional goat breeders. Therefore, the use of fermented feed technology to save time providing feed, as well as the use of a communal cage system for efficiency and effectiveness in the management of goat farms, needs to be trained and mastered by goat breeders. The purpose of this IbM is to develop the capability of the goat business and increase the yields of goat farmers in the village of Sindon, kec. Ngemplak kab. Boyolali Some solutions offered to help partner problems are (1) introduction and training to goat breeders in Sindon village, Ngemplak district, Boyolali Regency regarding the use of fermented feed technology for integrated management of goat livestock, (2) training and providing technology of leaf counting machines for the production process of fermented feed goat livestock, (3) training and assistance for the management of goats by utilizing a communal cage system to increase the efficiency and effectiveness of the production process. The expected outcome of this IbM activity is to increase the ability of the goat business, increase income and the effectiveness of the goat farming process in Sindon village, Ngemplak district, Boyolali district.
\end{abstract}

Keywords: chopper machines, fermented feed, goat livestock, komuna cages

\begin{abstract}
abstrak
Permasalahan pakan ternak dan efisiensi proses produksi peternakan kambing, masih menjadi persoalan besar bagi para peternak kambing konvensional. Oleh karenanya, pemanfaatan teknologi pakan fermentasi untuk menghemat waktu penyediaan pakan, serta pemanfaatan sistem kandang komunal untuk efisiensi dan efektifitas dalam pengelolaan peternakan kambing sangat perlu dilatihkan dan dikuasai oleh peternak kambing. Tujuan IbM ini adalah pengembangan kemampuan usaha ternak kambing dan peningkatan hasil budidaya pada peternak kambing di desa Sindon, kec. Ngemplak kab. Boyolali. Beberapa solusi yang ditawarkan untuk membantu permasalahan mitra adalah (1) pengenalan dan pelatihan pada peternak kambing desa Sindon kecamatan Ngemplak Kabupaten Boyolali tentang pemanfaatan teknologi pakan fermentasi untuk pengelolaan ternak kambing terpadu, (2) pelatihan dan pemberian teknologi mesin pencacah dedaunan untuk proses produksi pakan fermentasi ternak kambing, (3) pelatihan dan pendampingan untuk pengelolaan ternak kambing dengan pemanfaatan sistem kandang komunal untuk peningkatan efisiensi dan efektifitas proses produksi. Luaran yang diharapkan dari kegiatan IbM ini adalah peningkatan kemampuan usaha ternak kambing, peningkatan pendapatan serta efektifitas proses budidaya ternak kambing di desa Sindon kecamatan Ngemplak kabupaten Boyolali.
\end{abstract}

Kata Kunci: kandang komuna, mesin pencacah, pakan fermentasi, ternak kambing

PENDAHULUAN

Kambing yang digolongkan sebagai ruminansia kecil mempunyai arti besar bagi rakyat kecil. Ditinjau dari aspek pengembangannya ternak kambing sangat potensial bila 
diusahakan secara komersial, hal ini disebabkan ternak kambing memiliki beberapa kelebihan dan potensi ekonomi antara lain: tubuhnya relatif kecil, cepat mencapai dewasa kelamin, pemeliharaannya relatif mudah, tidak membutuhkan lahan yang luas, investasi modal usaha relatif kecil, mudah dipasarkan sehingga modal usaha cepat berputar. Selain itu ternak kambing juga memiliki kelebihan lain yaitu: reproduksinya efisien dan dapat beranak 3 kali dalam 2 tahun, memiliki daya adaptasi yang tinggi terhadap lingkungan, tahan terhadap panas dan beberapa penyakit serta prospek pemasaran yang baik. Ternak kambing memiliki peluang yang tinggi sebagai komoditas ekspor, terutama ke Timur Tengah, sampai saat ini Indonesia belum mampu mengisi peluang ekspor kambing secara kontinyu sebab populasinya masih sangat sedikit. Setiap tahunnya sekitar 2,5 juta umat muslim yang menunaikan ibadah haji, wajib melakukan korban untuk membayar dam (denda), maka setidaknya minimal sekitar 2 juta ekor kambing dibutuhkan untuk kurban tersebut, dengan demikian peluang pasar komoditas ternak kambing sangat cerah dan terbuka lebar.

Permasalahan serius yang sering dihadapi oleh peternak kambing adalah upaya penyediaan pakan ternak ini yaitu pada saat musim kering dimana ketersediaan hijauan pakan ternak sangat kurang. Rendahnya kepemilikan lahan juga merupakan salah satu penyebab peternak dalam upaya penyediaan pakan ternak. Tidak jarang ditemui di suatu daerah bahwa permintaan atau kebutuhan ternak meningkat tajam, namun para peternak merasa kesulitan untuk memenuhi permintaan atau kebutuhan ternak yang berkualitas karena alasan penyediaan pakan. Sebenarnya upaya untuk memenuhi kekurangan pakan dapat dilakukan dengan cara penambahan konsentrat pada ransum, akan tetapi rendahnya modal yang dimiliki peternak atau kelompok peternak, belum mampu malakukan upaya ini. Jerami padi merupakan salah satu limbah hasil pertanian (padi) yang sangat melimpah dan terdapat hampir disemua daerah di Indonesia, apalagi di saat musim panen yang sampai saat kini belum dimanfaatkan dengan baik. Rendahnya kualitas jerami padi dan persepsi salah dari para petani bahwa jerami padi tidak disukai oleh ternak kambing merupakan kendala mendasar penggunaan jerami padi sebagai pakan ternak kambing.

Oleh karena itu, dalam rangka membantu memecahkan persoalan mitra dan mengembangkan usaha dari kelompok ternak kambing di desa Sindon kecamatan Ngemplak Kab. Boyolali, perlu diperkenalkan dan diaplikasikan teknologi pakan fermentasi berbasis bahan pakan hijauan yang banyak dijumpai di lokasi mitra dan pengelolaan kandang komunal untuk mengintensifkan sistem peternakan kambing yang diusahakan.

Mitra kelompok peternak kambing di desa Sindon berdasarkan survey dan kajian lapangan memiliki persoalan-persoalan, seperti berikut: 1) Belum memahami cara pengolahan pakan fermentasi dan pemanfaatannya dalam budidaya ternak kambing, 2) Peternak di desa Sindon masih memelihara ternaknya masih secara idividual dengan jumlah ternak peliharaan sebanyak 3-5 ekor per-peternak, 3) Kegiatan budidaya ternak kambing dilakukan sebagai sambilan, dengan pekerjaan pokoknya adalah sebagai petani atau buruh tani. Sehingga budidaya ternak kambing dilakukan dengan memanfaatkan 'sisa waktu'. 
Beberapa permasalahan yang masih dihadapi oleh kelompok ternak kambing di desa Sindon, Kecamatan Ngemplak Kab. Boyolali selama 2 (dua) tahun terakhir ini adalah: 1) Pengelolaan budidaya ternak kambing masih dilakukan sangat konvensional, belum menerapkan sistem intensifikasi peternakan dan penerapan pakan fermentasi. Sehingga persoalan ketidak cukupan asupan pakan ternak, seringkali terjadi yang berakibat kualitas ternak menurun, daya tahan tubuhnya rendah hingga mengalami kematian ternak; 2) Produktifitas peternak kambing masih sangat terbatas belum bisa memenuhi permintaan kebutuhan daging, keperluan konsumsi harian masyarakat di kecamatan Ngemplak dan sekitarnya, seperti pedagang sate, aqiqah, dan kurban. Hal ini terkendala karena usaha budidaya masih-masih secara individual dengan kapasitas ternak rata-rata hanya 3-5 ekor kambing.

Berdasarkan latar belakang dan permasalahan maka tujuan utama dari kegiatan ini adalah pengembangan kemampuan usaha ternak kambing dan peningkatan hasil budidaya pada kelompok peternak kambing desa Sindon kecamatan Ngemplak Kab. Boyolali, sedangkan tujuan khususnya adalah sebagai berikut: 1) Mengembangkan pengelolaan usaha ternak kambing pada kelompok peternak kambing desa Sindon Kec. Ngemplak, melalui pengelolaan peternakan kambing secara komunal dan intensif; 2) Menerapkan teknologi pakan fermentasi untuk meningkatkan produktifitas dan efisiensi budidaya ternak kambing, sehingga dapat meningkatkan kesejahteraan para peternak kambing di kelompok peternak desa Sindon kec. Ngemplak; 3) Meningkatkan keterlibatan tenaga kerja terutama wanita dan pemuda usia produktif dari warga sekitar dengan pengelolaan lahan pekarangan dan ladang untuk budidaya tanaman pakan ternak yang bernilai ekonomis, meningkatkan kapasitas produksi dan pengembangan usaha ternak kambing melalui perbaikan proses pengelolaan dan budidaya ternak kambing; 4) Meningkatkan kemampuan sumber daya manusia dari UMKM dan mendekatkan peran LPPM UMS dalam pengembangan usaha kecil di wilayah kecamatan Ngemplak kabupaten Boyolali.

\section{METODE PENGABDIAN MASYARAKAT}

Permasalahan pengelolaan ternak kambing yang sangat konvensional, perhatian yang belum fokus dan hanya menjadi sambilan dan biaya yang belum efisien. Peternak akan diperkenalkan dan dibantu untuk memanfaatkan sistem kandang komunal dalam budidaya ternak kambing. Pemanfaatan kandang komunal diharapkan peternak menjadi lebih fokus \& perhatian, efiensi tenaga dan waktu, kualitas pakan dan kesehatan ternak lebih terjaga, disamping untuk menjaga mutu daging ternak kambing dan harga jual kambing.

Secara keseluruhan, peternak kambing di desa Sindon ini akan dilaksanakan dengan metode pendekatan sebagai berikut: 1) Pelatihan dan pendampingan cara pembuatan pakan fermentasi; 2) Pelatihan pemanfaatan teknologi pencacah dedaunan untuk proses pembuatan pakan ternak; 3) Pengenalan dan pelatihan pemanfaatan sistem kandang komunal; 4) Pendampingan untuk pencatatan perkembangan ternak, dan perawatan kesehatan ternak; 5) Pendampingan untuk dihubungkan dengan mitra calon pembeli ternak kambing, seperti usaha Aqiqah, pedagang sate dan tengkleng yang banyak tersebar di wilayah Solo Raya.

Pelatihan dan pendampingan pembuatan pakan fermentasi dengan memanfaatkan 
teknologi pakan fermentasi dan mesin pencacah dedaunan diharapkan dapat membantu peternak kambing untuk menjaga ketersediaan dan kualitas pakan ternak kambing. Pelatihan dan pemanfaatan sistem kandang komunal bagi peternak kambing, diharapkan peternak menjadi lebih fokus, kualitas dan kesehatan ternak lebih terjaga karena sebelum masuk kandang, ternak ditimbang (untuk dicatat bobot sebelumnya, tiap bulan dan saat panen).

Secara keseluruhan dengan memanfaatkan teknologi budidaya dan pengolahan pakan ternak yang tepat, system kandang komunal dan teknologi proses produksi yang optimal, maka diharapkan akan terjadi multifier effect berupa peningkatan jumlah petani/peternak yang terlibat, mendapatkan tambahan penghasilan, omset penjualan produk yang meningkat dan peningkatan kesejahteraan dari anggota kelompok peternak.

Tahap I. Pengenalan dan pelatihan kepada kelompok peternak desa Sindon tentang pemanfaatan teknologi budidaya kambing terpadu yang dapat digunakan untuk mengembangkan usaha ternak kambing, meningkatkan kapasitas produksi maupun kualitas produk daging dan susu kambing yang mungkin untuk dikembangkan. Teknologi proses produksi yang dikenalkan dan dilatihkan kepada kelompok peternak desa Sindon antara lain: (1) Teknologi kandang komunal dan penerapan pakan fermentasi untuk peningkatan produktifitas daging kambing yang diternakkan; (2) Budidaya bahan pakan secara intensif dan terpadu untuk mendukung ketersediaan pakan, (3) Mesin perajang dedaunan atau jerami untuk formulasi pakan ternak.

Tahap II. Pelatihan tenaga kerja dalam budidaya dan pengolahan pakan ternak, penggunaan mesin proses produksi, cara operasional peralatan, dan cara mengatasi permasalahan jika ada gangguan mesin saat dioperasikan.

Tahap III. Pelatihan cara budidaya dan pengolahan pakan ternak. Pada tahap ini para peternak dari kelompok peternak desa Sindon ditargetkan dapat memiliki pengetahuan dan ketrampilan untuk budidaya dan pengolahan pakan ternak kambing, sehingga ketersedian dan kualitas pakan ternak kambing dapat terjaga dengan baik.

Tahap IV. Pemberian modal / investasi berupa modal kerja untuk budidaya tanaman pakan ternak kambing, bahan-bahan untuk pengolahan pakan ternak, mesin untuk mengembangkan produktifitas daging.

Tahap V. Perluasan pemasaran dengan membentuk jaringan/networking dengan para pengepul dan pengusaha layanan aqiqah banyak berkiprah di daerah Solo Raya dan sekitarnya.

Tahap VI. Evaluasi dan monitoring untuk melakukan perbaikan, dan pengembangan usaha ternak kambing. Akan dilibatkan banyak pihak yang ahli dan berkompeten seperti Dinas Peternakan, dan Dinas Pertanian untuk senantiasa mendukung dan membantu pengembangan usaha ternak kambing ini. Setelah mendapatkan pelatihan dan bantuan modal teknologi yang akan diintroduksikan, diharapkan ketersediaan dan kualitas pakan ternak senantiasa terjaga, kapasitas produksi dan pengembangan penggemukan ternak kambing meningkat. Peningkatan pengembangan penggemukan kambing sebesar $200 \%$ ini dapat dicapai karena pemeliharaan dan standar pakan ternak dapat terjaga dengan 
baik. Budidaya ternak kambing lokal dan memiliki 3 (sisi) nilai ekonomis, yaitu 1) penjualan ternak kambing siap potong, 2) pemanfaatan limbah pertanian untuk pembuatan pakan ternak fermentasi. 3) pengolahan limbah ternak untuk pembuatan kompos.

Pengelolaan budidaya kambing yang lebih terpadu ini, akan memberikan keuntungan yang lebih besar bagi anggota kelompok peternak desa Sindon kec. Ngemplak Boyolali. Jika selama ini usaha ini hanya menjadi sambilan dari para petani, maka pengembangan usaha ternak kambing terpadu ini akan menjadi sumber penghasilan kedua yang memberikan hasil pendapatan yang besar juga bagi peternak. Jika selama ini jumlah ternak yang dikelola oleh peternak masing-masing hanya 3-5 ekor kambing, maka jika dikelola dengan system kandang komunal akan dipelihara lebih dari 30 ekor kambing oleh kelompok peternak desa Sindon ini. Modal usaha, aset dan pendapatan hasil usaha tentu akan lebih bertambah, karena optimasi dan efisiensi budidaya ternak kambing akan semakin meningkat.

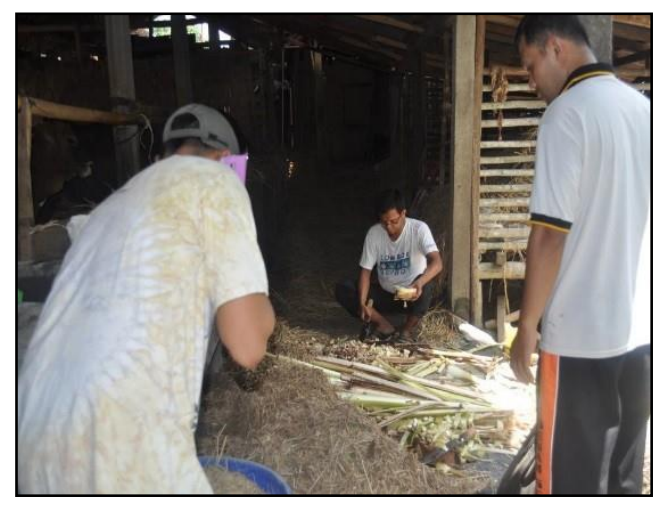

(a)

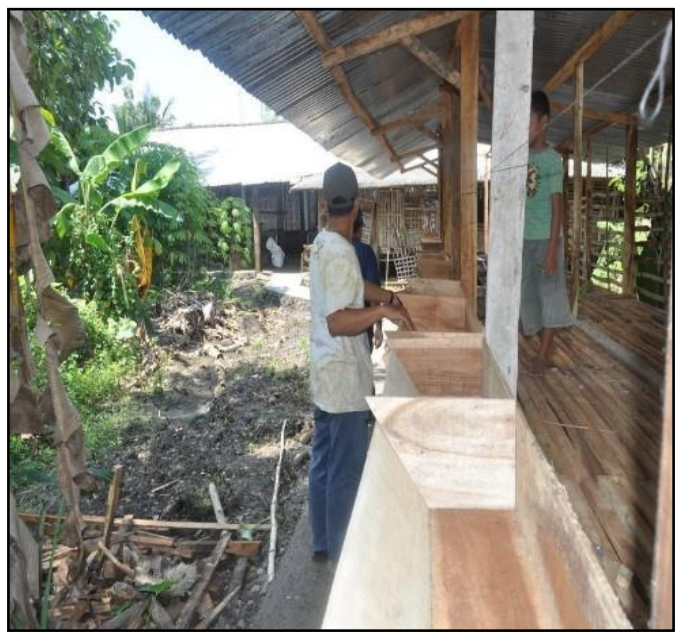

(b)

Gambar 1. (a) Penyiapan pembuatan pakan fermentasi, (b) Penataan dan perbaikan kandang kambing

\section{HASIL DAN PEMBAHASAN}

Dari dua permasalahan utama yang dihadapi oleh mitra peternak kambing, yaitu persoalan ketersediaan pakan ternak yang kurang rutin dan berkecukupan nilai gizinya serta produktifitas pemeliharaan peternakan kambing, melalui kegiatan IbM ini telah menunjukkan indikasi keberhasilan yaitu : 1) Pengetahuan dan ketrampilan pembuatan pakan fermentasi, telah membantu peternak kambing untuk menjaga ketersediaan dan kualitas pakan ternak. Dengan memanfaatkan teknologi mesin perajang yang diintroduksi dengan kapasitas produksi 1 kwintal per-jam, peternak hanya butuh waktu 2 minggu sekali untuk penyediaan pakan ternak sejumlah 10 ekor. Peternak memiliki waktu yang lebih untuk melakukan kegiatan usaha yang produktif; 2) Telah diperkenalkan teknologi mesin perajang dedaunan, untuk memproduksi pakan ternak secara mandiri dan berkelompok. Pemanfaatan mesin perajang sangat membantu 
peternak dalam proses perajangan bahan-bahan pakan; 3) Perkembangan bobot ternak kambing menunjukkan hasil cukup menggembirakan, walaupun pertambahan bobot ternak baru mencapai 1,5-2 kg per-bulan. Pertambahan bobot ternak ideal adalah 1,5-2

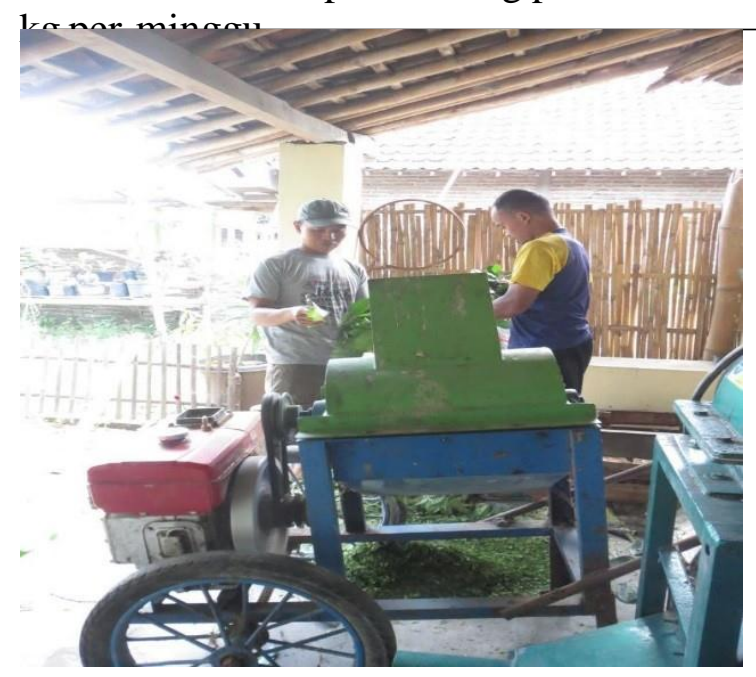

(a)

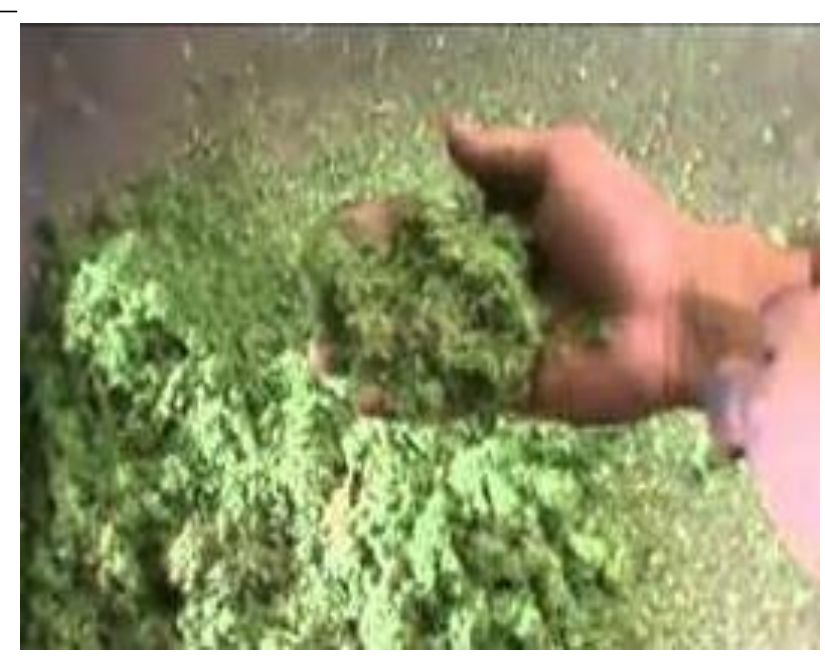

(b)

Gambar 3. (a) Gambar perajangan dedaunan untuk bahan pakan fermentasi, (b) hasil perajangan dalam $2 \mathrm{X}$ penggilingan

Pada tahap I petani peternak yang berhasil didatangkan sebanyak 40 petani peternak, dengan catatan kehadiran petani peternak tidak lepas dari peranan Surat Kepala Dinas Pangan dan Pertanian Pemerintah Kabupaten Sidoarjo. Dalam pelaksanaan tatap muka diketahui bahwa rerata para petani peternak memiliki kendala-kendala tertentu dalam peningkatan kompetensi.

Kendala yang masih dihadapi yakni: 1) Ketersediaan bahan pakan, seperti rendeng kaca, daun tebu, daun jagung, dll sangat terbatas di lingkungan mitra, sehingga produktifitas pakan olahan fermentasi belum optimal dengan kapasitas produksi mesin perajang; 2) Produksi pakan olahan fermentasi yang dihasilkan oleh mitra belum dijual untuk peternak lain, karena peternak lain belum memahami dan belum terbiasa menggunakan pakan fermentasi.

\section{PENUTUP \\ Simpulan}

Pengetahuan dan ketrampilan produksi pakan olahan fermentasi secara mandiri, telah mampu meningkatkan efisiensi waktu pembuatan pakan ternak. Pemanfaatan teknologi yang diintroduksikan telah meningkatkan kapasitas produksi pakan, walaupun belum dapat dipasarkan ke peternal lain Pertumbuhan bobot ternak kambing telah menunjukkan hasil, walaupun belum ideal.

\section{Saran}

Untuk meningkatkan pendapatan peternak, perlu dilaksanakan pendampingan untuk promosi dan pemasaran produk pakan ternak hasil olahan peternak mitra kepada peternal lain. Untuk mengoptimalkan pemanfaatan mesin perajang yang telah 
diintroduksi, perlu pendampingan untuk pengembangan produksi pupuk organik dengan memanfaatkan limbah kotoran kambing dan limbah dedaunan yang cukup melimpah di lingkungan mitra.

\section{UCAPAN TERIMA KASIH}

Tim pengabdian kepada masyarakat mengucapkan terima kasih atas bantuan pendanaan dari Direktorat Riset dan Pengabdian Masyarakat, Direktorat Jenderal Penguatan Riset dan Pengembangan, Kementerian Riset, Teknologi dan Pendidikan Tinggi. Tim pengabdian kepada masyarakat juga mengucapkan terima kasih kepada pimpinan institusi terkait atas bantuan kelancaran kegiatan pengabdian kepada masyarakat ini.

\section{DAFTAR PUSTAKA}

Astuti P, Sukarni S. 2004. Kinerja Domba Lokal yang Mendapatkan Limbah Padat (Blotong ) Industri Pabrik Gula. Karanganyar: APEKA.

Djajanegara, A. 1983. "Intake and digestion of cerealvstraws by sheep". Thesis. University of Melbourne.

Handayanta E. 2003. Potensi Limbah Industri Pengolahan Kedelai sebagai Bahan Suplementasi dalam Ransum Ternak Domba. Karanganayar: APEKA.

Saifuddin, I.A., 2003. "Pertumbuhan Pra Sapih Anak Kambing Pada Zona Ketinggian yang Berbeda di Kabupaten Kulon Progo DIY". Skripsi, Fakultas Peternakan Universitas Gadjah Mada.

Tilman, A.D. et. al. 1991. Ilmu makanan ternak dasar. Yogyakarta: Gadjah Mada University Perss

Yunilas. 2009. Bioteknologi Jerami Padi Melalui Fermentasi Sebagai Bahan Pakan ternak Ruminansia. USU repository. 